\title{
Modulation of rat preadipocyte adipose conversion by androgenic status: involvement of C/EBPs transcription factors
}

\author{
E Garcia ${ }^{1}$, M Lacasa ${ }^{2}$, B Agli ${ }^{1}$, Y Giudicelli ${ }^{1}$ and D Lacasa ${ }^{1}$ \\ ${ }^{1}$ INSERM CJF 94-02, Faculté de Médecine Paris-Ouest, Université René Descartes, Paris V, Centre Hospitalier de Poissy, Poissy 78303, France \\ ${ }^{2}$ Université Paris VI, France \\ (Requests for offprints should be addressed to Y Giudicelli, INSERM CJF 94-02, Service de Biochimie, CHI, 78303 Poissy, France)
}

\begin{abstract}
Androgenic status affects rat preadipocyte adipose conversion from two deep intra-abdominal (epididymal and perirenal) fat depots differently. The aim of this study was to establish whether these site-specific alterations of adipogenesis are related to altered expressions of the transcriptional factors regulating proliferation and differentiation of preadipocytes, c-myc and CCAAT/enhancer binding proteins (C/EBPs: C/EBP $\alpha$ and $\beta$ ).

The increased proliferation of epididymal and perirenal preadipocytes from castrated rats was not linked to variations in c-myc mRNA and protein levels.

The expression of the early marker of adipogenesis, lipoprotein lipase (LPL), was decreased by androgenic deprivation in epididymal cells but remained insensitive to the androgenic status in perirenal preadipocytes. In contrast, LPL expression increased in subcutaneous preadi-
\end{abstract}

pocytes from castrated rats, an effect which was partly corrected by testosterone treatment.

Expression of C/EBP $\beta$ was unaffected by androgenic status whatever the anatomical origin of the preadipocytes. In contrast, the mRNA and protein levels of $\mathrm{C} / \mathrm{EBP} \alpha$ were greatly decreased by androgenic deprivation in epididymal cells, an alteration which could not be corrected by in vivo testosterone administration.

Altogether these results demonstrated that in preadipocytes androgenic deprivation affects site-specifically the expression of LPL, an early marker of adipogenesis and of $\mathrm{C} / \mathrm{EBP} \alpha$, a master regulator of adipogenesis. These observations contribute to an explanation of why castration induces defective adipose conversion in rat epididymal preadipocytes specifically.

Journal of Endocrinology (1999) 161, 89-97

\section{Introduction}

It is well established that fat tissue development and distribution depend on sex steroid hormones. Android obesity, an important risk factor for cardiovascular diseases, is characterized by excessive accumulation of adipose tissue in abdominal and visceral regions (Bjorntorp 1991, 1996).

The presence of specific androgen receptors has been described in both precursors and mature fat cells $(\mathrm{Xu}$ et al. 1990, Dieudonné et al. 1998). Furthermore, these receptors are up-regulated by testosterone and their density varies with the anatomical origin of preadipocytes (De Pergola et al. 1990, Dieudonné et al. 1998) and during adipogenesis (Dieudonné et al. 1995, 1998). This suggests that adipose tissue might be a target for androgens.

In rats, we have previously reported that castration induces a decreased adipose tissue weight, in particular, in the epidydimal fat deposits (Lacasa et al. 1993). One possible explanation for these reduced adiposities could be that castration restrains the capacities of fat cell precursors to proliferate and/or to differentiate. In fact, we have observed, in rat epididymal preadipocytes but not in subcutaneous (SC) ones, that castration induces an increase in their proliferative capacity and, conversely, a decrease in their ability to differentiate (Lacasa et al. 1995). More recently, we have also shown that castration increases adipoconversion of perirenal preadipocytes. Furthermore, the increased proliferation of epididymal and perirenal preadipocytes is associated with high mitogen-activated protein (MAP) kinase activity (Lacasa et al. 1997).

Cell proliferation and differentiation processes are tightly controlled at the nuclear level by transcriptional factors which are cell specific or not. Among these factors, the product of the proto-oncogene c-myc, whose expression is activated by mitogenic signals, binds to DNA specific sequences leading to enhanced transcriptional activity controlling cellular proliferation (Amati \& Lands 1994). Thus, c-myc could regulate the expression of different genes required for cell-cycle progression. On the other hand, in various cell types and tissues, c-myc expression has been shown to be regulated by sex-steroid hormones (Schuchard et al. 1993). For example, testosterone treatment reduces $\mathrm{c}-\mathrm{myc}$ mRNA level, in vivo, in the 
rat ventral prostate (Quarmby et al. 1987) and, in vitro, in human prostatic cells (Wolf et al. 1992).

Some members of the family of transcription factors, CCAAT/enhancer binding proteins (C/EBPs) such as $\mathrm{C} / \mathrm{EBP} \alpha, \mathrm{C} / \mathrm{EBP} \beta$ and $\mathrm{C} / \mathrm{EBP} \partial$, are important regulators of adipocyte differentiation. $\mathrm{C} / \mathrm{EBP} \beta$ and $\mathrm{C} / \mathrm{EBP} \partial$, are induced early during adipocyte differentiation in response to hormonal stimulators (Cao et al. 1991). In turn, these factors stimulate the expression of $\mathrm{C} / \mathrm{EBP} \alpha$ which, then, activates its own expression and that of a set of adipospecific genes such as $422 / \mathrm{aP} 2$ and SCD1 which all have functional $\mathrm{C} / \mathrm{EBP}$-binding sites in their promoters (Christy et al. 1989). Furthermore, C/EBP $\alpha$ is an inhibitor of cell proliferation by inducing the expression of the growth-arrested-associated gene gadd 45 and the cyclindependent kinase inhibitor p21 (Constance et al. 1993, Timchenko et al. 1996).

Concerning the hormonal regulation of these transcription factors, the level of $\mathrm{C} / \mathrm{EBP} \alpha$ expression has been reported to be repressed by glucocorticoids in 3T3-L1 adipocytes (MacDouglas et al. 1994), but positively regulated by oestrogens in rat ovarian follicles (Piontkewitz et al. 1993).

Expression of C/EBP $\beta$ is rapidly induced by glucocorticoids in liver and intestine (Boudreau et al. 1996, Matsuno et al. 1996) but not in 3T3-L1 adipocytes (MacDouglas et al. 1994). It has been suggested that adipogenesis could be reciprocally regulated by $\mathrm{c}-\mathrm{myc}$ and $\mathrm{C} / \mathrm{EBP} \alpha$. In fact, in the 3T3-L1 preadipocyte cell line, overexpression of c-myc resulted in the inhibition of $\mathrm{C} / \mathrm{EBP} \alpha$ induction and consequently prevented adipogenesis. Conversely, overexpression of $\mathrm{C} / \mathrm{EBP} \alpha$ overcomes the inhibitory effects of $\mathrm{Myc}$ on adipogenesis (Freytag \& Geddes 1992).

It may thus be suggested that modified expression of c-myc and consequently of $\mathrm{C} / \mathrm{EBP} \alpha$ could explain the defective adipogenesis observed in epididymal cells after castration. In order to test this hypothesis, we have presently compared the effects of androgenic status on the expression of $\mathrm{c}-\mathrm{myc}$ and $\mathrm{C} / \mathrm{EBP} \alpha$ (mRNA and protein), as well as on early events of adipogenesis in rat preadipocytes from two intra-abdominal (epididymal and perirenal) and one SC (femoral) localizations.

\section{Materials and Methods}

\section{Materials}

Fetal bovine serum (FBS) was obtained from Gibco-BRL (Grand Island, NY, USA). Phenol red-free Dulbecco's modified Eagle's medium (DMEM) and DMEM-Ham's F12 (50:50 mix) were obtained from Sigma Chemical Co. (St Louis, MO, USA). The antisera and synthetic peptides specific for C/EBP $\alpha$ (SC61), C/EBP $\beta$ (SC130) and GADD153/CEBP Homologous Protein (CHOP) (SC793) were from Santa Cruz Biotechnology (Santa Cruz, CA,
USA). The antiserum specific for c-myc (OP30) was from Oncogene Science (Cambridge, MA, USA). Western blotting protocols and random sequence hexanucleotide primers DNA labelling (Megaprime kit) were from Amersham International plc (Amersham, Bucks, UK). The PCR purification kit (QUIAquick) was obtained from Quiagen (Santa Clarina, CA, USA). Restriction enzymes (Bam HI and Sal I) were purchased from Promega (Madison, WI, USA). Testosterone RIA tests were provided by Biomérieux (Marcy l'Etoile, France). All other chemicals were of reagent grade.

\section{Animals}

Procedures with experimental animals were authorized and followed the guidelines of the Ministry of Agriculture (France) (authorization 006614). Male Sprague-Dawley rats $(125-150 \mathrm{~g})$ were castrated under pentobarbital anaesthesia $(40 \mathrm{mg} / \mathrm{kg}$ i.p.) and treated as previously described (Lacasa et al. 1993, 1995). Briefly, 5 days after the operation, half of the castrated rats received one s.c. injection of testosterone propionate $(0.5 \mathrm{mg} / 100 \mathrm{~g}$ body weight) every other day for 10 days (cast+T) while the other half (cast) and the sham-operated rats (sham) received the vehicle (propyleneglycol) only. One day after the last injection, rats were killed by decapitation. Serum testosterone levels were measured as described in Lacasa et al. (1993) and were on the day of death: $1 \cdot 5 \pm 0 \cdot 2$, less than 0.1 and $13.5 \pm 3.7 \mathrm{nmol} / 1$ in sham, cast and cast $+\mathrm{T}$ rats. The characteristics of SC and epididymal adipose tissues of the different experimental groups were given in Lacasa et al. (1993). Perirenal adipose tissue weights were: $3 \cdot 05 \pm 0 \cdot 28,2 \cdot 90 \pm 0 \cdot 30$ and $2 \cdot 8 \pm 0 \cdot 28 \mathrm{~g}$ for sham, cast and cast $+\mathrm{T}$ rats.

\section{Cell culture}

Cell preparation and culture were performed as described in Deslex et al. (1987). Briefly, preadipocytes obtained from the stroma-vascular fraction of adipose tissue by collagenase digestion were plated at a density of $1-2 \times 10^{4}$ cells $/ \mathrm{cm}^{2}$ in $8 \%$ FBS-DMEM. After $12 \mathrm{~h}$, cultures were washed and fed with 8\% FBS-DMEM. Medium was changed every other day. At confluence (3 days postplating), cells were allowed to differentiate in DMEMHam's F12 containing $5 \mu \mathrm{g} / \mathrm{ml}$ insulin, $10 \mu \mathrm{g} / \mathrm{ml}$ transferrin and $200 \mathrm{pM}$ tri-iodothyronine (ITT medium) and in the absence of serum as described in Deslex et al. (1987). Whatever the anatomical origin, at least $80 \%$ of the control cells in culture were fully differentiated at days 8-10 post-confluence.

c-myc expression was examined in proliferating preadipocytes cultured for 1-2 days post-plating in $8 \%$ FBS-DMEM and then serum-deprived for $18 \mathrm{~h}$. Early differentiated preadipocytes (EDP) (2-3 days in ITT medium) were used for lipoprotein lipase (LPL) and 
$\mathrm{C} / \mathrm{EBP} \beta$ expression studies while $\mathrm{C} / \mathrm{EBP} \alpha$ expression was investigated in late-differentiated preadipocytes (LDP) (6-8 days in ITT medium).

\section{Preparation of cellular extracts}

Preadipocyte fraction was prepared as follows. Proliferating or differentiated preadipocytes were scraped and sonicated in cold buffer containing $50 \mathrm{mM}$ Tris (pH 8.0), $120 \mathrm{mM}$ $\mathrm{NaCl}, 1 \mathrm{mM}$ EDTA, $1 \%$ NP40, 0.1\% SDS, $0.57 \mathrm{mM}$ PMSF, $0.5 \mathrm{mM}$ sodium deoxycholate, $1 \mathrm{mM}$ orthovanadate, $30 \mathrm{mM} \beta$-glycerophosphate, $25 \mu \mathrm{g} / \mathrm{ml}$ aprotinin and $20 \mu \mathrm{g} / \mathrm{ml}$ leupeptin. After centrifugation at $100000 \mathrm{~g}$ for $15 \mathrm{~min}$ at $4{ }^{\circ} \mathrm{C}$, the resulting supernatant was denaturated with Laemmli buffer (v:v) and stored at $-20{ }^{\circ} \mathrm{C}$.

\section{Western blot analysis}

Equal amounts of protein $(20-75 \mu \mathrm{g})$ and prestained molecular weight markers were subjected to SDS-PAGE (12.5\%-15\% acrylamide). Proteins were transferred to polyvinylidenedifluoride membranes. The filters were subsequently stained to verify equal protein loading and transfer. After blocking by Tris-buffered saline (TBS) containing $0 \cdot 1 \%$ Tween 20 (TBS-T) and $2 \cdot 5 \%$ gelatin for $2 \mathrm{~h}$, filters were incubated overnight with the primary antibody diluted in TBS-T/2.5\% gelatin $(0.5 \mu \mathrm{g} / \mathrm{ml})$. Membranes were washed and incubated with the secondary antiserum coupled to peroxidase (1:5000 dilution in TBS-T) for $1 \mathrm{~h}$ and extensively washed with TBS-T. Filters were next incubated with the enhanced chemiluminescence detection solution and then exposed to X-ray films. Reprobing of the membranes gave identical results. Specificity of the immunoreactive proteins was verified by loss of sample immunoreactivity when incubated with the antiserum neutralized with the corresponding specific peptide. Signals were quantified by densitometry. Control experiments with various amounts of protein $(10-75 \mu \mathrm{g})$ were performed to ensure that the densitometric signal intensity was proportional to the amount of protein loaded.

\section{Northern blot analysis}

Total RNAs were extracted following the acidguanidinium-isothiocyanate protocol as previously described (Chomczynski \& Sacchi 1987). RNA samples (20-40 $\mu \mathrm{g})$ were separated on denaturing gels containing $1 \%$ agarose, $12.5 \%$ formaldehyde. The electrophoresed RNAs were capillary transferred onto a Hybond $\mathrm{N}^{+}$ membrane in $20 \times$ SSC and cross-linked to this membrane $\left(1 \mathrm{~h}\right.$ at $\left.80^{\circ} \mathrm{C}\right)$. Prehybridizations were carried out for $3 \mathrm{~h}$ at $68^{\circ} \mathrm{C}$ in Church solution $(0.5 \mathrm{M}$ sodium phosphate, $1 \mathrm{mM}$ EDTA and 7\% SDS). Hybridizations with ${ }^{32} \mathrm{P}-\mathrm{cDNA}$ probes labelled by random priming $(2-5$ $10^{8}$ d.p.m. $/ \mu \mathrm{g}$ ) were performed overnight at $68^{\circ} \mathrm{C}$. The hybridized membranes were then washed twice in $2 \times$ SSC, $0 \cdot 1 \%$ SDS at room temperature for $15 \mathrm{~min}$ and once in $0.5 \times \mathrm{SSC}, 0.1 \% \mathrm{SDS}$ at $65^{\circ} \mathrm{C}$ for $5 \mathrm{~min}$ before being exposed to an $\mathrm{X}$-ray film at $-80^{\circ} \mathrm{C}$. The band intensities were quantified by densitometry. Membranes were next dehybridized in boiling 0.5\% SDS and then hybridized with probe specific for the ribosomal acidic protein $\mathrm{PO}$ chosen as an internal control because its expression is sex-steroid independent (La Borda 1991).

To verify the integrity of the loaded RNA, parallel gels were run and stained with ethidium bromide to visualize $28 \mathrm{~S}$ and $18 \mathrm{~S}$ ribosomal RNAs.

The CMV-NF-IL6 vector was obtained by inserting a $1 \mathrm{~kb}$ Sal I fragment containing the NF-IL6 coding region into one Sal I site of CMVp eucaryotic vector (Akira et al. 1990). A $1.3 \mathrm{~kb}$ Not I fragment containing the C/EBP $\alpha$ coding region was inserted into one Not I site of CMVp eucaryotic vector. The resulting plasmid was named hCMV-C/EBPa (Timchenko et al. 1995). The probes were specific for rat $\mathrm{c}$-myc and ribosomal acidic protein PO as described in Nishimura et al. (1992) and La Borda (1991) respectively. The oligonucleotide primer pairs specific for rat LPL were: sense 5'-GCGGATTTC

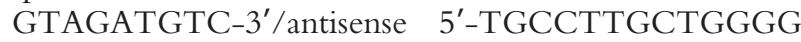
TTTTC- $3^{\prime}$. These probes were prepared by RT-PCR methods using rat proliferating preadipocyte RNA (c-myc, ribosomal acidic protein $\mathrm{PO}$ ) and rat adipocyte RNA (LPL). The PCR products were purified with a PCR purification kit.

\section{Other determinations}

Protein concentrations were measured following the dyebinding procedure (Bradford 1976) using bovine serum albumin as standard. All results are expressed as means \pm s.E.M. from at least three individual experiments. Comparisons between groups were made using analysis of variance with Bonferroni $P$ values.

\section{Results}

As previously reported (Lacasa et al. 1994, 1995, 1997) and summarized in Table 1, androgenic status affects adipose conversion of preadipocytes differently according to their anatomical origin. To obtain more information on these effects at a molecular level, we studied the expression of some transcription factors involved in preadipocyte proliferation and differentiation.

\section{Androgenic status and c-myc expression}

Serum-stimulated expression of c-myc was first studied in proliferating preadipocytes from different fat depots.

In preliminary experiments using cells deprived of serum for $18 \mathrm{~h}$, we found that $\mathrm{c}-\mathrm{myc}$ mRNA and protein 
Table 1 Influence of castration on adipoconversion of preadipocytes from different anatomical localizations in the rat

\section{Anatomical origin} of fat depots Femoral SC Epididymal Perirenal

\section{Proliferative capacity (cell number)}

\section{Differentiation capacity (GPDH activity)}

$\begin{array}{ll}\text { Unchanged } & \begin{array}{l}\text { Unchanged } \\ \text { Increased }\end{array} \\ \text { Increased } & \begin{array}{l}\text { Decreased } \\ \text { Increased }\end{array}\end{array}$

expressions were maximally induced after $1-\mathrm{h}$ and 3-h serum exposure respectively.

It should be noted that from several experiments, no reproducible differences in c-myc expression (mRNA and protein) could be observed between SC and deep intra-abdominal preadipocytes from control rats (data not shown).

As shown in Figs 1 and 2, the steady-state levels of c-myc mRNA and protein were both decreased by castration in epididymal preadipocytes. However, in vivo treatment by testosterone failed to reverse these effects.

These experiments indicate that the increased proliferation of deep intra-abdominal preadipocytes induced by castration is not linked to variations in c-myc expression.

\section{Androgenic status and early events of adipogenesis}

Androgenic status differently influences the adipoconversion process in deep intra-abdominal preadipocytes as SC epididymal perirenal

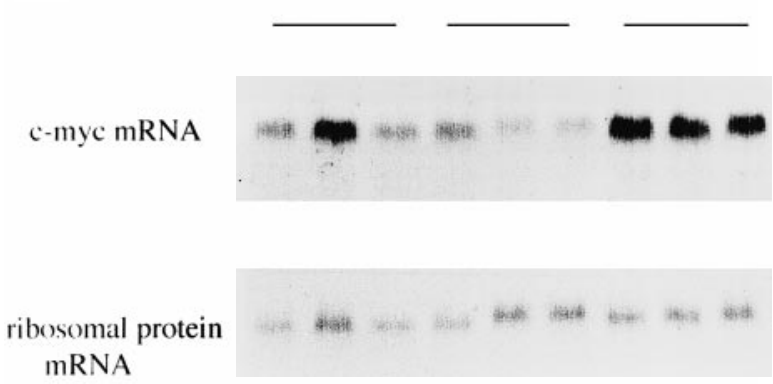

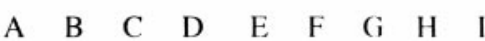

assessed by morphological observations and glycerol-3phosphate dehydrogenase (GPDH) activity, a late marker of differentiation (Lacasa et al. 1995, 1997). To examine whether the early steps of adipogenesis are also affected by androgenic status, the expression of one marker of these events, LPL (Ailhaud et al. 1992) was measured in EDP from the different fat depots. When normalized to ribosomal protein, LPL expression was found to be identical in preadipocytes from sham rats whatever their anatomical origin. However, as shown in Fig. 3, LPL expression was almost completely abolished by castration in epididymal EDP, a defect which could not be restored to control values by in vivo testosterone treatment. Surprisingly, LPL expression was markedly enhanced $(+250 \%)$ by castration in SC EDP, an effect which was completely prevented by testosterone replacement. In contrast, however, perirenal EDP were found to be insensitive to the androgenic status in terms of LPL expression.

These observations indicate that castration alters sitespecifically an early marker of adipogenesis such as LPL whose expression is either increased in SC, or decreased in epididymal or unchanged in perirenal EDP.

\section{Androgenic status and the C/EBPs transcriptional factors}

$\mathrm{C} / \mathrm{EBP} \beta$ which is expressed early during the course of adipogenesis activates the expression of $\mathrm{C} / \mathrm{EBP} \alpha$ which is then positively autoregulated (MacDouglas \& Lane 1995).

Therefore, to gain more information about the molecular basis underlying the effects of castration on adipogenesis

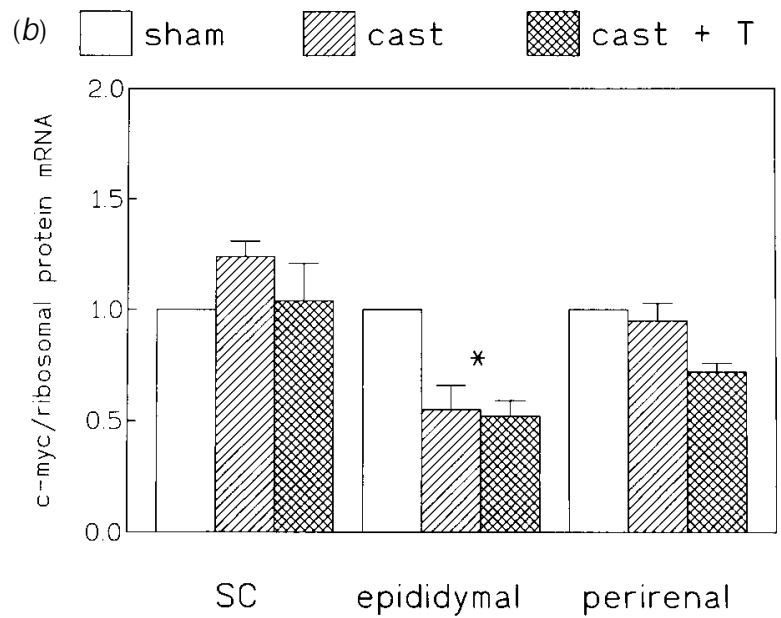

Figure 1 Influence of androgenic status on c-myc mRNA expression in rat proliferating preadipocytes from femoral SC, epididymal and perirenal fat depots. Total RNAs of proliferating preadipocytes from femoral SC (A, B and C), epididymal $(D, E$ and $F)$ and perirenal $(G, H$ and I) fat depots from sham $(A, D$ and $G)$, cast $(B, E$ and $H)$ and cast $+T(C, F$ and $I)$ rats were hybridized with rat c-myc probe. (a) Representative Northern blot of c-myc mRNA. (b) Densitometric analysis of c-myc Northern blots. The data are means \pm S.E.M. of five separate experiments. (b) This figure shows variations in c-myc mRNA/ribosomal protein mRNA percentage ratios. 100\% is assigned to each type of preadipocyte from sham rats (control) for c-myc mRNA and ribosomal protein mRNA. Then, for each experimental group, the respective c-myc mRNA and ribosomal protein mRNA were expressed relative to the corresponding controls. Next, c-myc mRNA/ribosomal protein mRNA percentage ratios were calculated. ${ }^{*} P<0 \cdot 05$, cast and cast $\mathrm{T}$ vs sham. 
(a)

$$
\text { c-myc protein }
$$

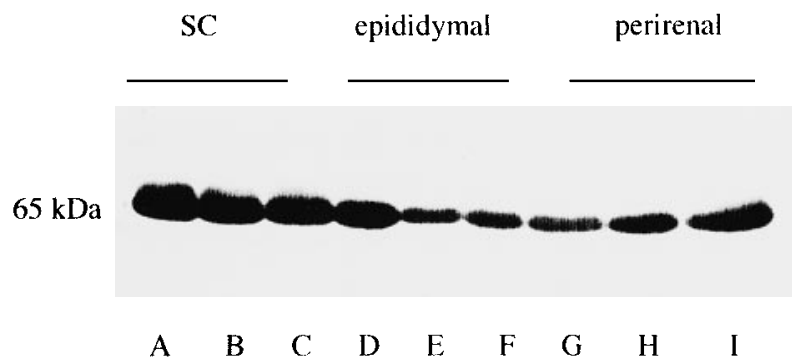

(b)
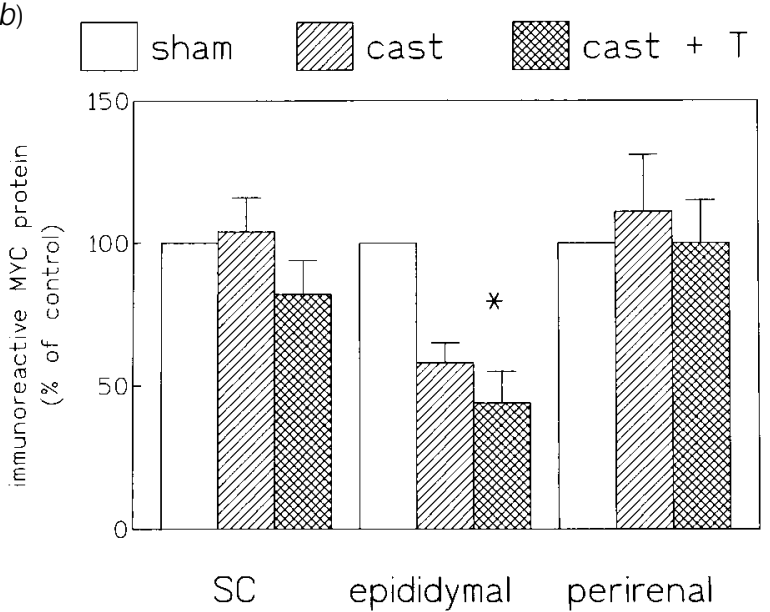

Figure 2 Influence of androgenic status on c-myc protein expression in rat proliferating preadipocytes from femoral SC, epididymal and perirenal fat depots. Cellular extracts of proliferating preadipocytes from femoral SC (A, B and C), epididymal (D, E and F) and perirenal $(\mathrm{G}, \mathrm{H}$ and $\mathrm{I})$ fat depots from sham $(\mathrm{A}, \mathrm{D}$ and $\mathrm{G})$, cast $(\mathrm{B}, \mathrm{E}$ and $\mathrm{H})$ and cast $+\mathrm{T}(\mathrm{C}, \mathrm{F}$ and $\mathrm{I})$ rats were probed with rat c-myc antiserum. (a) Representative Western blot of c-myc protein. (b) Densitometric analysis of c-myc Western blots. The data are means \pm S.E.M. of five separate experiments and are expressed as percentage of control values (100\% is assigned to each type of preadipocyte from sham rats). ${ }^{*} P<0 \cdot 05$, cast and cast $T$ vs sham.

(a)

SC epididymal perirenal

LPL mRNA

ribosomal protein mRNA

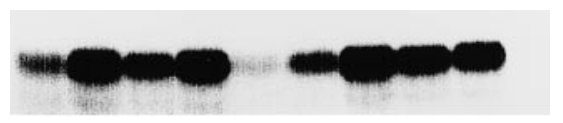

A B C D F F (b)

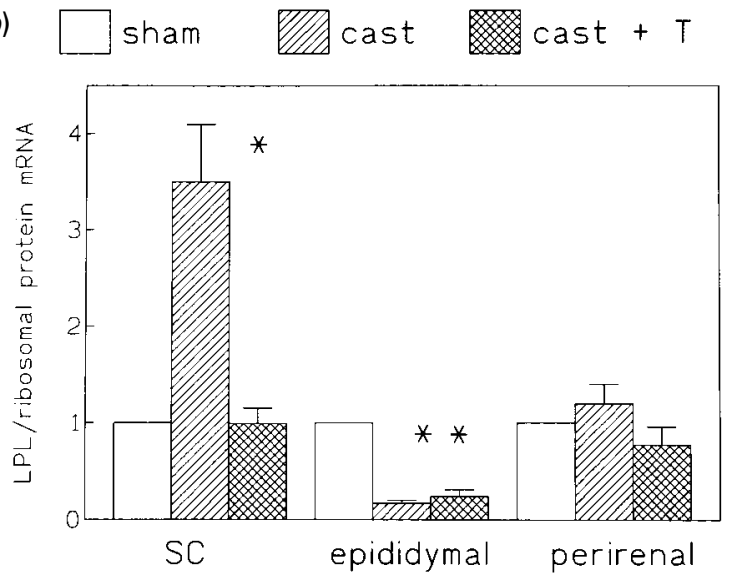

Figure 3 Influence of androgenic status on LPL mRNA expression in rat differentiated preadipocytes from femoral SC, epididymal and perirenal fat depots. Total RNAs of differentiated preadipocytes from femoral SC (A, B and C), epididymal (D, E and F) and perirenal $(G, H$ and $I)$ fat depots from sham $(A, D$ and $G)$, cast $(B, E$ and $H)$ and cast $+T(C, F$ and $I)$ rats were hybridized with rat $L P L$ probe. (a) Representative Northern blot of LPL mRNA. (b) Densitometric analysis of LPL Northern blots. The data are means \pm S.E.M. of six separate experiments. (b) The figure shows variations in LPL mRNA relative to ribosomal protein mRNA. 100\% is assigned to each type of preadipocyte from sham rats (control) for LPL mRNA and ribosomal protein mRNA. Then, for each experimental group, the respective LPL mRNA and ribosomal protein mRNA were expressed relative to the corresponding controls. Next, LPL mRNA/ribosomal protein mRNA percentage ratios were calculated. ${ }^{*} P<0 \cdot 05$, cast vs cast $\mathrm{T}$ and sham; ${ }^{*} P<0 \cdot 05$, cast and cast $\mathrm{T}$ vs sham.

described above, expressions of these transcriptional factors (mRNA and protein) were next studied. C/EBP $\beta$ mRNA and protein expressions were found to be unaffected by the androgenic status whatever the anatomical origin of EDP (Fig. 4).
A single $\mathrm{C} / \mathrm{EBP} \alpha$ mRNA has been shown to give rise to two major alternative translation products, $\mathrm{p} 42$ $\mathrm{C} / \mathrm{EPB} \alpha$ and $\mathrm{p} 30 \mathrm{C} / \mathrm{EBP} \alpha$ (Ossipow et al. 1993). $\mathrm{C} / \mathrm{EBP} \alpha \mathrm{mRNA}$ level was greatly decreased in epididymal LDP from castrated rats (Fig. 5). Similarly, the levels 


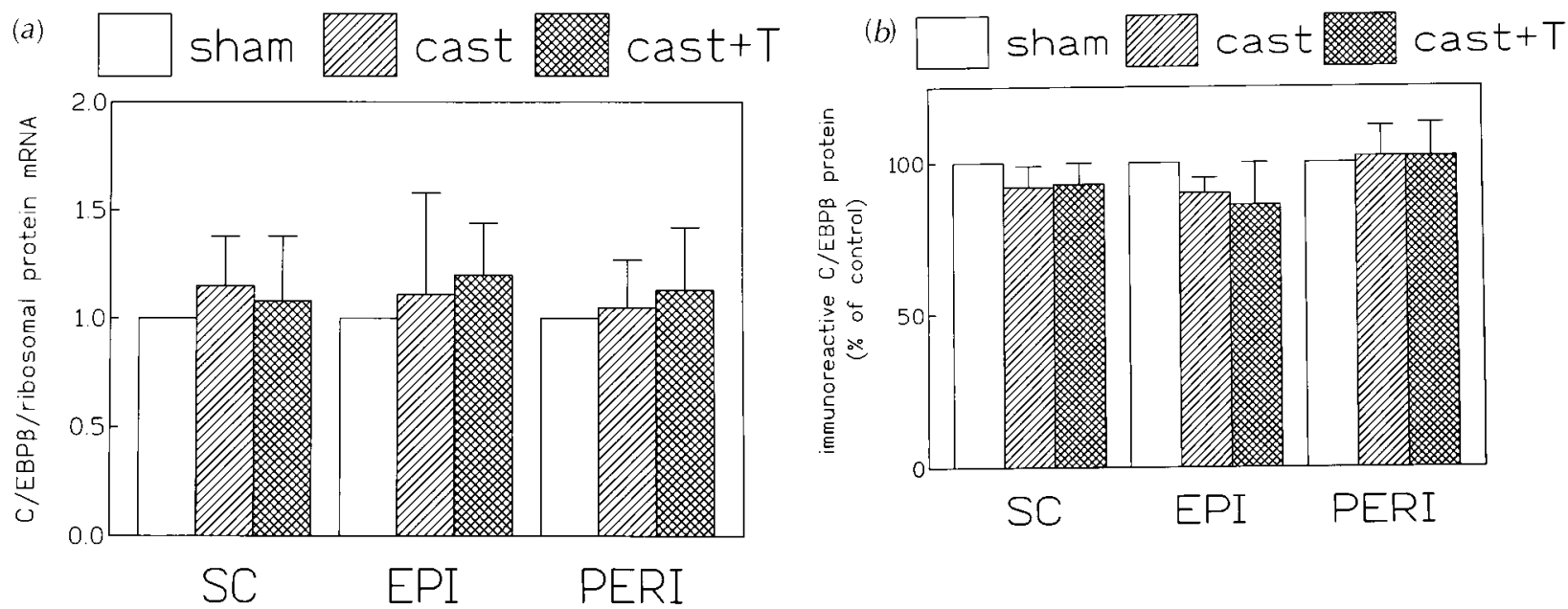

Figure 4 Influence of androgenic status on C/EBP $\beta$ mRNA and protein expression in rat differentiated preadipocytes from SC, epididymal and perirenal fat depots. (a) Densitometric analysis of C/EBP $\beta$ Northern blots. Total RNA of differentiated preadipocytes from femoral SC, epididymal (EPI) and perirenal (PERI) fat depots from sham, cast and cast+T rats were hybridized with C/EBP $\beta$ probe. The data are means \pm S.E.M. of five separate experiments. The graph shows $C / E B P \beta \mathrm{mRNA} /$ ribosomal protein mRNA percentage ratios. $100 \%$ is assigned to each type of preadipocyte from sham rats (control) for C/EBP $\beta$ mRNA and ribosomal protein mRNA. Then, for each experimental group, the respective C/EBP $\beta$ mRNA and ribosomal protein mRNA were expressed relative to the corresponding controls. Next, C/EBP $\beta$ mRNA/ribosomal protein mRNA percentage ratios were calculated. (b) Densitometric analysis of C/EBP $\beta$ Western blots. Cellular extracts of differentiated preadipocytes from femoral SC, epididymal and perirenal fat depots from sham, cast and cast+T rats were probed with $\mathrm{C} / \mathrm{EBP} \beta$ polyclonal antiserum. The data are means \pm S.E.M. of five separate experiments and are expressed as percentage of control values $(100 \%$ is assigned to each type of preadipocyte from sham rats).

(a)

C/EBP $\alpha$
mRNA

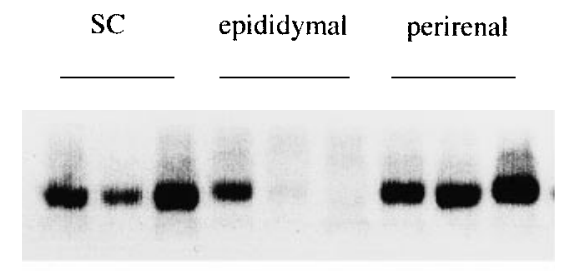

ribosomal protein mRNA

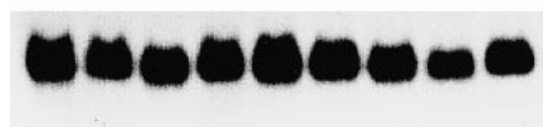
A

(b)

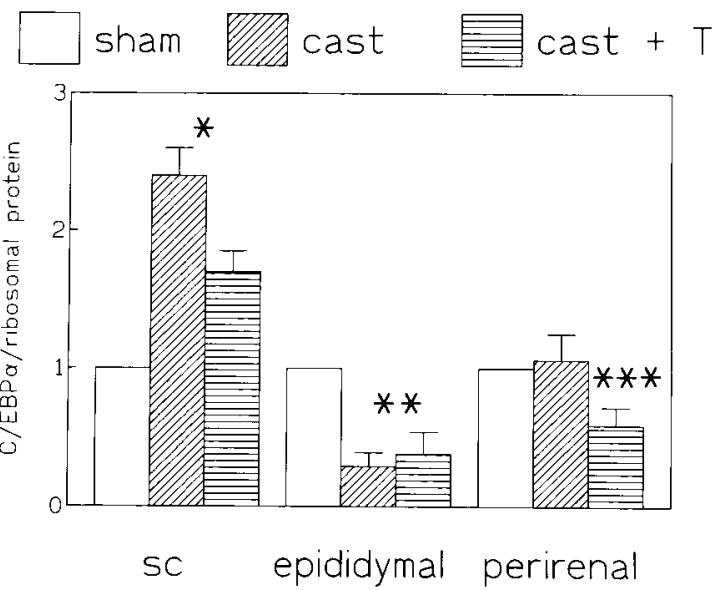

Figure 5 Influence of androgenic status on C/EBP $\alpha$ mRNA expression in rat differentiated preadipocytes from femoral SC, epididymal and perirenal fat depots. Total RNAs of differentiated preadipocytes from femoral SC (A, B and C), epididymal (D, E and F) and perirenal $(\mathrm{G}, \mathrm{H}$ and $\mathrm{I})$ fat depots from sham $(\mathrm{A}, \mathrm{D}$ and $\mathrm{G})$, cast $(\mathrm{B}, \mathrm{E}$ and $\mathrm{H})$ and cast+T $(\mathrm{C}, \mathrm{F}$ and $\mathrm{I})$ rats were hybridized with $\mathrm{C} / \mathrm{EBP} \alpha \mathrm{probe}$. (a) Representative Northern blot of C/EBP $\alpha$ mRNA. (b) Densitometric analysis of C/EBP $\alpha$ Northern blots. The data are means \pm S.E.M. of five separate experiments. (b) This figure shows variations in C/EBP $\alpha$ mRNA relative to ribosomal protein mRNA. $100 \%$ is assigned to each type of preadipocyte from sham rats (control) for C/EBPa mRNA and ribosomal protein mRNA. Then, for each experimental group, the respective $\mathrm{C} / \mathrm{EBP} \alpha \mathrm{mRNA}$ and ribosomal protein mRNA were expressed relative to the corresponding controls. Next, $\mathrm{C} / \mathrm{EBP} \alpha$ mRNA/ribosomal protein mRNA percentage ratios were calculated. ${ }^{\star} P<0 \cdot 05$, cast vs sham and cast $\mathrm{T}$; ${ }^{* \star} P<0 \cdot 05$, cast and cast $\mathrm{T}$ vs sham; $* * * P<0 \cdot 05$, cast $T$ vs sham and cast.

of p42 and the p30 doublet isoforms resulting from post-translational modification (MacDouglas \& Lane 1995) were diminished by castration (Fig. 6). In vivo testosterone treatment failed to correct these defects (Figs 5 and 6). In contrast, in perirenal LDP, C/EBP $\alpha \mathrm{mRNA}$ level was unaffected by castration but decreased $(-40 \%, P<0 \cdot 05)$ 
(a)

\section{C/EBP $\alpha$ protein}

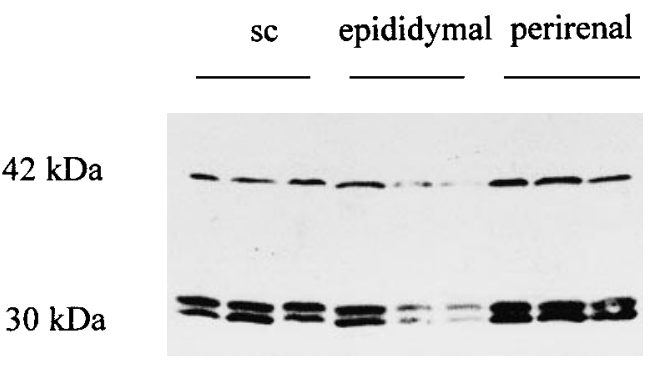

$\begin{array}{llllllllll}\text { A } & \text { B } & \text { C } & \text { D } & \text { E } & \text { F } & \text { G } & \text { H } & \text { I }\end{array}$

(b)
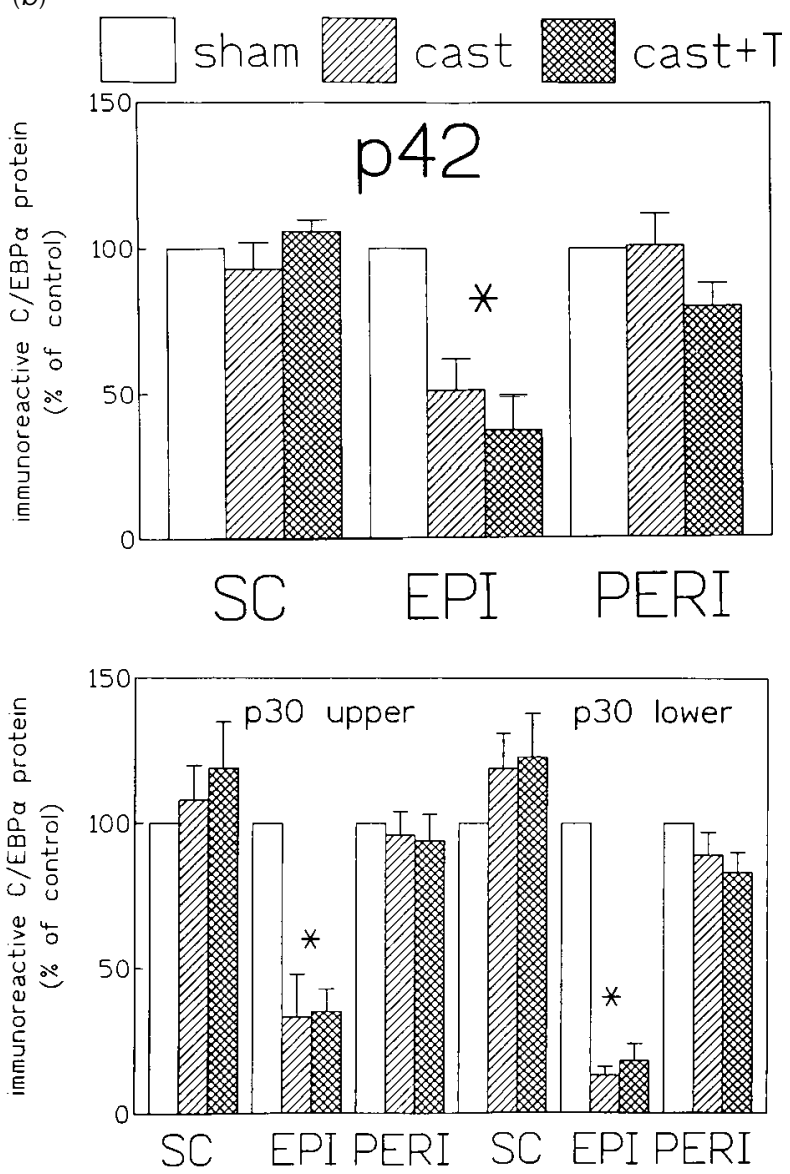

Figure 6 Influence of androgenic status on C/EBP $\alpha$ protein expression in rat differentiated preadipocytes from femoral SC, epididymal and perirenal fat depots. Cellular extracts of differentiated preadipocytes from femoral SC (A, B and C), epididymal (D, E and $F$ ) and perirenal $(G, H$ and $I)$ fat depots from sham $(A, D$ and $G)$, cast $(B, E$ and $H)$ and cast+T $(C, F$ and $I)$ rats were probed with $\mathrm{C} / \mathrm{EBP} \alpha$ polyclonal antiserum. (a) Representative Western blot of C/EBP $\alpha$ protein. (b) Densitometric analysis of $\mathrm{C} / \mathrm{EBP} \alpha$ Western blots. The data are means \pm S.E.M. of five separate experiments and are expressed as percentage of control values ( $100 \%$ is assigned to each type of preadipocyte from sham rats). ${ }^{\star} P<0 \cdot 05$, cast and cast $T$ vs sham. by testosterone treatment. Finally, in SC LDP, castration induced a significant increase in $\mathrm{C} / \mathrm{EBP} \alpha \mathrm{mRNA}$ but not in $\mathrm{C} / \mathrm{EBP} \alpha$ protein expression, an effect which was partly prevented by testosterone replacement.

Taken together these data strongly suggest that the defective adipogenesis observed in epididymal LDP after castration is linked to a decreased expression of the transcriptional factor $\mathrm{C} / \mathrm{EBP} \alpha$ but not of its upstream activator $\mathrm{C} / \mathrm{EBP} \beta$.

\section{Discussion}

We have previously reported that the adipogenesis of deep intra-abdominal preadipocytes studied in vitro is differently affected by the androgenic status depending on the anatomical origin of the precursor cells. In fact, we found that the differentiation process was either enhanced or completely inhibited by castration in perirenal and epididymal preadipocytes respectively (Lacasa et al. 1995, 1997).

In contrast, both epididymal and perirenal preadipocytes elicited increased proliferation capacities after castration (Lacasa et al. 1995, 1997). The latter finding led us to hypothesize that the androgenic status may alter c-myc induction in response to serum mitogenic factors in both perirenal and epididymal preadipocytes. As shown in the present study, however, this hypothesis can be ruled out since the steady-state levels of c-myc mRNA and protein were found to be unchanged in perirenal and even decreased in epididymal preadipocytes after castration. This negative observation suggests that, like in Swiss 3T3 fibroblasts (Mehmet et al. 1997), only low levels of Myc are sufficient to reach full mitogenic response of rat preadipocytes, e.g. that above a given level, $\mathrm{c}-\mathrm{myc}$ protein would not further increase the preadipocyte proliferation rate.

With regard to the early events of adipogenesis, our results clearly show that androgen deprivation substantially abolishes the expression of the early marker LPL in epididymal preadipocytes but not in perirenal cells. In the early steps of the differentiation process, LPL expression has been shown to be regulated, at least in part, through the cAMP signalling pathway (Couturier et al. 1998) while, later on, LPL is induced by transactivators such as peroxysome proliferator-activated receptors $\gamma(\operatorname{PPAR} \gamma s)$ and members of the C/EBP family (Spiegelman \& Flier 1996). We have previously observed that castration specifically blunted the cAMP production by confluent and differentiated preadipocytes (D Lacasa \& B Agli, unpublished results). Thus this alteration could be responsible for the decreased LPL expression in these cells.

However, as shown in the present study, castration increases and in vivo testosterone treatment decreases LPL expression without altering the adipogenic capacities of SC cells (Lacasa et al. 1995). These findings are consistent with our previous observation showing that the lipogenic 
activity $\left({ }^{3} \mathrm{H}\right.$ glucose incorporation into triacylglycerol) was either enhanced in rat SC adipocytes or decreased in epididymal cells by castration (Lacasa et al. 1993). On the whole, these results indicate that androgen deprivation influences, in two opposite ways, the lipogenic pathway of SC and epididymal adipocytes mainly through a positive or negative regulation of LPL expression.

The mechanisms whereby castration site-specifically influences the lipogenic pathway remain unsettled. In any case, these site-related opposite effects cannot be related to differences in androgen receptor (AR) densities since AR numbers are lower in SC than in deep intra-abdominal preadipocytes (De Pergola et al. 1990, Dieudonné et al. 1998) and AR are down-regulated by castration whatever the anatomical origin of the cells (Dieudonné et al. 1998).

Expression of C/EBP $\beta$ appears unaffected by the androgenic status, suggesting that modified expression of this transcriptional factor is not involved in the defective adipogenesis of epididymal preadipocytes.

A different situation was observed concerning the expression of $\mathrm{C} / \mathrm{EBP} \alpha$, another member of this transcriptional factor family.

As shown in the present study, the steady-state levels of $\mathrm{C} / \mathrm{EBP} \alpha \mathrm{mRNA}$ and protein are dramatically decreased in epididymal preadipocytes after castration. Under our experimental conditions, in vivo testosterone administration was unable to restore to normal C/EBPa expression. Since CHOP, the product of a growtharrested-associated gene (gadd 153) belonging to the $\mathrm{C} / \mathrm{EBP}$ family, is a negative modulator of $\mathrm{C} / \mathrm{EBP} \alpha, \beta$ and $\partial$ (MacDouglas \& Lane 1995), we have also examined the expression of CHOP in epididymal preadipocytes. Our preliminary results indicate, however, an apparent insensitivity of CHOP expression to castration (data not shown). The present study also indicates that the expression of $\mathrm{C} / \mathrm{EBP} \beta$, another $\mathrm{C} / \mathrm{EBP} \alpha$ modulator, is unaltered by the androgenic status in epididymal cells. It is worthy of note that these cells exhibit a reduced number of lipid droplets due to defective lipogenic capacities (Lacasa et al. 1995). Thus, fatty acid (FA) availability is probably reduced in these cells and consequently the transcriptional activity of PPAR $\gamma$ because FAs are physiological activators of this transcription factor (Spiegelman \& Flier 1996). Since a positive regulatory loop has been postulated between PPAR $\gamma$ and C/EBP $\alpha$ (Brun et al. 1997), reduced $\operatorname{PPAR} \gamma$ transcriptional activity could well contribute to explain why the differentiation process in epididymal cells cannot proceed and why various adipocyte genes including $\mathrm{C} / \mathrm{EBP} \alpha$ are not induced after castration.

$\mathrm{C} / \mathrm{EBP} \alpha$ has a strong antiproliferating role by inducing the growth-arrested-associated gene, gadd 45 , and the cyclin-dependent kinase inhibitor p21 (Constance et al. 1993, Timchenko et al. 1996). Thus, the reduced expression of $\mathrm{C} / \mathrm{EBP} \alpha$ observed in epididymal preadipocytes after castration could contribute to an explanation of the increased proliferation capacities of these cells but not of the perirenal preadipocytes where $\mathrm{C} / \mathrm{EBP} \alpha$ expression is not modified by castration. Further experiments will be needed to establish whether inductions of $\mathrm{p} 21$ and gadd 45 by $\mathrm{C} / \mathrm{EBP} \alpha$ are differently affected by castration in epididymal and perirenal preadipocytes.

Expression of C/EBP $\alpha$ which is sufficient to trigger adipogenesis is positively autoregulated to maintain the fully differentiated state of the cells (MacDouglas \& Lane 1995). Because of all the properties of $\mathrm{C} / \mathrm{EBP} \alpha$, the low level of $\mathrm{C} / \mathrm{EBP} \alpha$ expression found in epididymal preadipocytes after castration could provide a convenient explanation not only for the increased proliferative capacity, but also for the defective adipogenesis characterizing these cells. However, the mechanisms underlying the site-specific differences in $\mathrm{C} / \mathrm{EBP} \alpha$ modulation by androgen deprivation in preadipocytes remain to be determined.

Recent experiments from our laboratory indicate that in vivo testosterone administration up-regulates $\mathrm{AR}$ number in epididymal preadipocytes from castrated rats (Dieudonné MN, unpublished results). However, as shown here, this treatment failed to correct some of the alterations induced by castration (i.e. LPL and C/EBP $\alpha$ expressions) in these cells. This indicates that these alterations cannot fully account for androgen and/or AR deficiencies. These observations rather suggest that lack of some products of the testis other than testosterone (steroidal and non-steroidal testicular factors) could play a significant role in these effects of castration.

In conclusion, this study provides strong evidence that the mechanism whereby androgenic status specifically depresses the adipose conversion of epididymal preadipocytes, involves, at least in part, a reduced expression of $\mathrm{C} / \mathrm{EBP} \alpha$, a master regulator of adipogenesis.

\section{Acknowledgements}

We wish to thank G Darlington for providing hCMV-C/ EBP $\alpha$ plasmid and T Kishimoto for CMV-NF-IL6 plasmid. This work was supported by INSERM (CJF 94-02), Université de Paris V and the Comité des Yvelines de la Ligue contre le Cancer. E G was sponsored by a doctoral fellowship from the Comite des Yvelines de la Ligue contre le Cancer.

\section{References}

Ailhaud G, Grimaldi P \& Negrel R 1992 Cellular and molecular aspects of adipose tissue development. Annual Review of Nutrition 12 207-233.

Akira S, Isshiki H, Sugita T, Tanabe O, Kinoshita S, Nishio Y, Nakajima T, Hirano T \& Kishimoto T 1990 A nuclear factor for IL-6 expression (NF-IL6) is a member of a C/EBP family. EMBO Journal 9 1897-1906.

Amati B \& Lands H 1994 Myc-Max-Mad: a transcription factor network controlling cell cycle progression, differentiation and death. Current Opinion in Genetics and Development 4 102-108. 
Bjorntorp P 1991 Metabolic implications of body fat distribution. Diabetes Care 14 1132-1143.

Bjorntorp P 1996 The regulation of adipose tissue distribution in humans. International Journal of Obesity 20 291-302.

Boudreau F, Blais S \& Asselin C 1996 Regulation of CCAAT/ enhancer binding protein isoforms by serum and glucocorticoids in the rat intestinal crypt cell line IEC-6. Experimental Cell Research 222 1-9.

Bradford MM 1976 A rapid and sensitive method for the quantification of microgram quantities of protein utilizing the principle of proteindye binding. Analytical Biochemistry 72 248-254.

Brun RP, Kim JB, Hu E \& Spiegelman BM 1997 Peroxisome proliferator-activated receptor gamma and the control of adipogenesis. Current Opinion in Lipidology 8 212-218.

Cao Z, Umek RM \& McKnight SL 1991 Regulated expression of three $\mathrm{C} / \mathrm{EBP}$ isoforms during adipose conversion of 3T3-L1 cells. Genes and Development 5 1538-1552.

Chomczynski P \& Sacchi N 1987 Single step method of RNA isolation by acid guanidium thiocyanate-phenol-chloroform extraction. Analytical Biochemistry 162 156-159.

Christy RJ, Yang VW, Ntambi JM, Geiman DE, Landchulz WH, Friedman AD, Nakabeppu Y, Kelly TJ \& Lane D 1989 Differentiation-induced gene expression in 3T3-L1 preadipocytes: CCAAT/enhancer binding protein interacts with and activates the promoters of two adipocyte-specific genes. Genes and Development 3 1323-1335.

Constance C, Morgan J \& Umek R 1993 C/EBP alpha regulation of the growth-arrested-associated gene gadd 45. Molecular and Cellular Biology 16 3878-3883.

Couturier C, Janvier B, Girlich D, Bereziat G \& Andreani-Mangeney M 1998 Effects of caffeine on lipoprotein lipase gene expression during the adipocyte differentiation process. Lipids 33 455-460.

De Pergola G, Xu X, Yang S, Giorgino R \& Bjorntorp P 1990 Up-regulation of androgen receptor binding in male rat fat pad adipose precursor cells exposed to testosterone: study in a whole assay system. Journal of Steroid Biochemical and Molecular Biology 37 553-558.

Deslex S, Negrel R \& Ailhaud G 1987 Development of a chemically defined serum-free medium for differentiation of rat adipose precursor cells. Experimental Cell Research 168 15-30.

Dieudonné MN, Pecquery R, Leneveu MC, Jaubert AM \& Giudicelli Y 1995 Androgen receptors in cultured rat adipose precursor cells during proliferation and differentiation: regional specificities and regulation by testosterone. Endocrine 3 537-541.

Dieudonné MN, Pecquery R, Boumediene A, Leneveu MC \& Giudicelli Y 1998 Androgen receptors in human preadipocytes and adipocytes: regional specificities and regulation by sex steroids. American Journal of Physiology 274 C1645-C1652.

Freytag SO \& Geddes TJ 1992 Reciprocal regulation of adipogenesis by myc and C/EBP $\alpha$. Science 256 379-382.

La Borda J 1991 36B4 cDNA used as an estradiol-independent mRNA control is the cDNA for human acidic ribosomal phosphoprotein PO. Nucleic Acids Research 193998.

Lacasa D, Agli B, Dieudonné MN \& Giudicelli Y 1993 Protein kinase $\mathrm{C}$ in rat adipocytes: status and regional fat distribution. Journal of Endocrinology 138 493-501.

Lacasa D, Denis D, Agli B, De Mazancourt P \& Giudicelli Y 1994 Rat preadipocyte adenylyl cyclase: influence of fat localization and androgenic status. Biochimica et Biophysica Acta 1224 527-532.

Lacasa D, Agli B, Moynard D \& Giudicelli Y 1995 Evidence for a regional-specific control of rat preadipocyte proliferation and differentiation by the androgenic status. Endocrine 3 789-793.
Lacasa D, Garcia E, Henriot D, Agli B \& Giudicelli Y 1997 Site-related specificities of the control by androgenic status of adipogenesis, MAP kinase cascade and c-fos signaling pathways in rat preadipocytes. Endocrinology 138 3181-3186.

MacDouglas OA, Cornelius P, Lin FT, Chen SS \& Lane MD 1994 Glucocorticoids reciprocally regulate expression of the CCAAT/ enhancer-binding protein $\alpha$ and $\delta$ genes in 3T3-L1 adipocytes and white adipose tissue. Journal of Biological Chemistry 269 19041-19047.

MacDouglas OA \& Lane MD 1995 Transcriptional regulation of gene expression during adipocyte differentiation. Annual Review of Biochemistry 64 345-373.

Matsuno F, Chowdhury S, Gotoh T, Iwase K, Matzsuzaki K, Takatsuki K, Mori M \& Takiguchi M 1996 Induction of the $\mathrm{C} / \mathrm{EBP} \beta$ by dexamethasone and glucagon in primary cultured rat hepatocytes. Journal of Biochemistry 119 524-532.

Mehmet H, Littlewood TD, Sinnett-Smith J, Moore JP, Evan GI \& Rozengurt E 1997 Large induction of c-myc is not essential for the mitogenic response of Swiss 3T3 fibroblasts. Cell Growth and Differentiation 8 187-193.

Nishimura J, Kobayashi S, Shikasho T \& Kanaide H 1992 Platelet derived growth factor induces c-fos and c-myc mRNA in rat aortic smooth muscle cells in primary culture without elevation of intracellular $\mathrm{Ca}^{2+}$ concentration. Biochemical and Biophysical Research Communications 188 1198-1204.

Ossipow V, Descombes P \& Schibler U 1993 CCAAT/enhancerbinding protein mRNA is translated into multiple proteins with different transcription activation potentials. Proceedings of the National Academy of Sciences of the USA 90 8219-8223.

Piontkewitz Y, Enerback S \& Hedin L 1993 Expression and hormonal regulation of the CCAAT/enhancer binding protein- $\alpha$ during differentiation of rat ovarian follicles. Endocrinology 133 2327-2333.

Quarmby VE, Beckman WC, Wilson EM \& French FS 1987 Androgen regulation of $\mathrm{c}-$ myc messenger ribonucleic acid levels in rat ventral prostate. Molecular Endocrinology 1 865-874.

Schuchard M, Landers JP, Sandhu NP \& Spelberg TC 1993 Steroid hormone regulation of nuclear proto-oncogenes. Endocrine Reviews 14 659-669.

Spiegelman BM \& Flier JS 1996 Adipogenesis and obesity: rounding out the big picture. Cell 87 377-389.

Timchenko N, Wilson DR, Taylor LR, Abdelsayed S, Wilde M, Sawadogo M \& Darlington GJ 1995 Autoregulation of the human $\mathrm{C} / \mathrm{EBP} \alpha$ gene by stimulation of upstream stimulatory factor binding. Molecular and Cellular Biology 15 1192-1202.

Timchenko N, Wilde M, Nakanishi M, Smith J \& Darlington G 1996 $\mathrm{CCAAT} /$ enhancer binding protein alpha $(\mathrm{C} / \mathrm{EBP} \alpha)$ inhibits cell proliferation through the p21 (WAF/CIP-1/SD-1) protein. Genes and Development 10 804-815.

Wolf DA, Kohlhuber F, Schulz P, Fittler F \& Eick D 1992 Transcriptional down-regulation of c-myc in human prostate carcinoma cells by the synthetic androgen mibolerone. British Journal of Cancer 65 376-382.

Xu X, De Pergola G \& Bjorntorp P 1990 The effects of androgens on the regulation of lipolysis in adipose precursor cells. Endocrinology 126 1229-1234.

Received 24 August 1998

Accepted 2 November 1998 